Meta

Journal des traducteurs

Translators' Journal

\title{
Film Adaptation as an Act of Communication: Adopting a Translation-oriented Approach to the Analysis of Adaptation Shifts
}

\section{Katerina Perdikaki}

Volume 62, numéro 1, avril 2017

URI : https://id.erudit.org/iderudit/1040464ar

DOI : https://doi.org/10.7202/1040464ar

Aller au sommaire du numéro

Éditeur(s)

Les Presses de l’Université de Montréal

ISSN

0026-0452 (imprimé)

1492-1421 (numérique)

Découvrir la revue

Citer cet article

Perdikaki, K. (2017). Film Adaptation as an Act of Communication: Adopting a Translation-oriented Approach to the Analysis of Adaptation Shifts. Meta, 62(1), 3-18. https://doi.org/10.7202/1040464ar

\section{Résumé de l'article}

Les avenues théoriques contemporaines en études d'adaptation et de traduction (Aragay 2005 ; Catrysse 2014 ; Milton 2009 ; Venuti 2007) envisagent des synergies entre ces deux domaines qui peuvent contribuer à la valeur socioculturelle et artistique des adaptations. Cela suggère l'application des aperçus théoriques dérivés des études de traduction à la transmission des livres sur l'écran (c.-à-d. l'adaptation cinématographique). Cet article établit que la procédure de transposition d'un roman à un produit cinématographique implique un acte de communication bidirectionnelle entre le livre, le film et les contextes de leur production et leur réception. Le rôle du contexte dans cette communication fait l'objet d'une attention particulière. Dans cet article, le contexte inclut le matériel paratextuel pertinent pour le texte adapté et le film. Ce paratexte peut mener à de fructueuses analyses des adaptations et, par conséquent, permettre de s'affranchir du critère restrictif de fidélité qui régit traditionnellement les études d'adaptation. La section analytique de l'article utilise des exemples d'interventions adaptatives (c.-à-d. entre le livre source et l'adaptation cinématographique) apparus dans le film P.S. I Love You (LaGravenese 2007). Ces exemples sont examinés à la lumière des entretiens avec l'auteur, le directeur et les acteurs, la bande-annonce du film et une critique cinématographique.
Ce document est protégé par la loi sur le droit d'auteur. L'utilisation des services d'Érudit (y compris la reproduction) est assujettie à sa politique d'utilisation que vous pouvez consulter en ligne.

https://apropos.erudit.org/fr/usagers/politique-dutilisation/ 


\title{
Film Adaptation as an Act of Communication: Adopting a Translation-oriented Approach to the Analysis of Adaptation Shifts
}

\author{
KATERINA PERDIKAKI \\ University of Surrey, Guildford, United Kingdom \\ k.perdikaki@surrey.ac.uk
}

\begin{abstract}
RÉSUMÉ
Les avenues théoriques contemporaines en études d'adaptation et de traduction (Aragay 2005; Catrysse 2014; Milton 2009; Venuti 2007) envisagent des synergies entre ces deux domaines qui peuvent contribuer à la valeur socioculturelle et artistique des adaptations. Cela suggère l'application des aperçus théoriques dérivés des études de traduction à la transmission des livres sur l'écran (c.-à-d. l'adaptation cinématographique). Cet article établit que la procédure de transposition d'un roman à un produit cinématographique implique un acte de communication bidirectionnelle entre le livre, le film et les contextes de leur production et leur réception. Le rôle du contexte dans cette communication fait l'objet d'une attention particulière. Dans cet article, le contexte inclut le matériel paratextuel pertinent pour le texte adapté et le film. Ce paratexte peut mener à de fructueuses analyses des adaptations et, par conséquent, permettre de s'affranchir du critère restrictif de fidélité qui régit traditionnellement les études d'adaptation. La section analytique de l'article utilise des exemples d'interventions adaptatives (c.-à-d. entre le livre source et l'adaptation cinématographique) apparus dans le film P.S. I Love You (LaGravenese 2007). Ces exemples sont examinés à la lumière des entretiens avec l'auteur, le directeur et les acteurs, la bande-annonce du film et une critique cinématographique.
\end{abstract}

\begin{abstract}
Contemporary theoretical trends in Adaptation Studies and Translation Studies (Aragay 2005; Catrysse 2014; Milton 2009; Venuti 2007) envisage synergies between the two areas that can contribute to the sociocultural and artistic value of adaptations. This suggests the application of theoretical insights derived from Translation Studies to the adaptation of novels for the screen (i.e., film adaptations). It is argued that the process of transposing a novel into a filmic product entails an act of bidirectional communication between the book, the novel and the involved contexts of production and reception. Particular emphasis is placed on the role that context plays in this communication. Context here is taken to include paratextual material pertinent to the adapted text and to the film. Such paratext may lead to fruitful analyses of adaptations and, thus, surpass the myopic criterion of fidelity which has traditionally dominated Adaptation Studies. The analysis uses examples of adaptation shifts (i.e., changes between the source novel and the film adaptation) from the film P.S. I Love You (LaGravenese 2007), which are examined against interviews of the author, the director and the cast, the film trailer and one film review.
\end{abstract}

\section{RESUMEN}

Las tendencias teóricas contemporáneas en los estudios de adaptación y de traducción (Aragay 2005, Catrysse 2014, Milton 2009, Venuti 2007) contemplan sinergias entre las dos áreas que pueden contribuir al valor sociocultural y artístico de las adaptaciones. Esto sugiere la aplicación de ideas teóricas derivadas de Estudios de Traducción a la adaptación de novelas para la pantalla (es decir, adaptaciones cinematográficas). Se 
argumenta que el proceso de transposición de una novela en un producto fílmico implica un acto de comunicación bidireccional entre el libro, la novela y los contextos involucrados de producción y recepción. Se hace especial hincapié en el papel que desempeña el contexto en esta comunicación. El contexto aquí se toma para incluir el material paratextual pertinente al texto adaptado y a la película. Tal paratexto puede llevar a análisis fructíferos de las adaptaciones y, por tanto, superar el criterio miope de fidelidad que tradicionalmente ha dominado los Estudios de Adaptación. El análisis utiliza ejemplos de cambios de adaptación (es decir, cambios entre la novela de origen y la adaptación cinematográfica) de la película P.S. I Love You (LaGravenese 2007), que son examinados en contra de las entrevistas del autor, el director y el reparto, el remolque de la película y una revisión de la película.

\section{MOTS-CLÉS/KEYWORDS/PALABRAS CLAVE}

adaptation, traduction, contexte, paratexte, interventions adaptatives adaptation, translation, context, paratext, adaptation shifts

adaptación, traducción, contexto, paratexto, cambios de adaptación

\section{Introduction}

Film adaptations have played a crucial part in the film industry recently, which can be seen as the outcome of the following trends (Corrigan 2014):

- Fruitful adaptations of classical texts from Shakespeare to Austen and others, which have inspired many distinct socio-political and ideological reinterpretations across eras and cultures;

- Blockbuster adaptations, such as the Harry Potter and Lord of the Rings series, which have commercially motored the film industry as well as related areas, such as toy manufacture and computer-game production; and

- Adaptations of graphic novels and comic books, which have lately served as the basis for an on-going interplay between graphic mise-en-scène and moving image.

Adaptations nowadays contribute to "convergence culture" (Corrigan 2014), which involves a circulation and re-mediation of texts, images, media and the concomitant communicated messages. In addition, such a phenomenon raises the question of what contributes to the ubiquity of adaptations and how such a trend can be systematically analysed.

The relationship between a novel and a film that is based on it can be juxtaposed with the one that exists between a source text and its translation. As theorists like Aragay (2005), Doloughan (2011), Krebs (2012) and Venuti (2007) have pointed out, the two processes have much in common. Notably, Krebs argues that investigation of the similarities between translation and adaptation can contribute to a more comprehensive "understanding of contemporary as well as historic constructions of culture" (Krebs 2012: 50). Catrysse (2014) builds on the common ground between adaptation and translation and proposes a descriptive approach to adaptation study based on polysystem theory. According to Catrysse (2014: 52), such a functional approach emphasises the role of adaptations in a given space-time context. In both translation and adaptation, semantic content is transferred from one product to another as well as from one context to another. The source text of the translation is situated in a context of production and reception, which includes the people involved in its writing, such as authors, editors and publishers, and those that are on the 
receiving end, such as readers and reviewers. The translated text has a similar context of production and reception, where the role of writer and mediator is reserved for the translator. Although the contexts of the two texts may be away from one another in spatial, temporal or sociocultural terms, the translating act carries over the transmission of a message, thus involving an implicit communication between them.

In fact, Venuti (2007) remarks that there is a hermeneutic orientation embedded in the process of translation, as it reflects the sociocultural values of a given period; these values are renegotiated in the translations that are produced across different communities and eras. Moreover, Lefevere, who viewed translation as rewriting and as a refraction, defined (literary) translation as "the adaptation of a work of literature to a different audience, with the intention of influencing the way in which that audience reads the work" (Lefevere 1982/2012: 205). This definition includes the crucial element of adaptation that a translation necessarily undergoes in order to respond to the receiving audience's needs and expectations; the translation reinterprets and renegotiates the issues dealt with in the source text and re-establishes them in a new context with different values and experiences. In a similar vein, Vandal-Sirois and Bastin (2012) argue that adaptation can be posited as functional translation in that it addresses a communication situation and caters to the needs of the target audience and culture. What is more, given the current era of globalization and the need for efficient multilingual intercultural communication, adaptation is evident in localization practices of advertising and marketing (Vandal-Sirois and Bastin 2012). As a result, the concept of adaptation can be expanded to refer to the transformation or manipulation a text is subject to when translated for a different audience and sociocultural context.

Similarly to the source and target texts of the translation, the adapted text and the filmic product are situated within their own contexts, with the adaptation process reconfiguring the communicative situation between them. As Leitch (2008: 117) remarks, the reinterpretation incited by adaptations largely depends on "the institutional contexts within which a given adaptation, and adaptations in general, are made available to [the individual members of the audience] and identified as such" (Leitch 2008: 117). In a similar vein, Venuti (2007: 30) underlines that the reinterpretation realised by the adaptation process is informed by the human agents involved as well as by economic, political and ideological factors. Venuti's (2007) claim resonates with Lefevere's (1982/2012) concept of patronage, which he elaborated with regard to translations and the literary system, as the latter is also affected by the multifarious agendas at play. In fact, patronage as defined by Lefevere (1982/2012) can be applied to the film system, which in turn bolsters the affinities between literature and cinema as systems and, by extension, those between Translation Studies and Adaptation Studies.

Adaptation-related research has so far investigated the differences between the two media (Wagner 1975) and what can be transferred and adapted (Chatman 1978; McFarlane 1996). Recently, the focus has shifted onto multimedia adaptation and participatory culture (Doloughan 2011; Jenkins 2006). Therefore, the notion of 'adaptation' in Film Studies and Adaptation Studies has surpassed the oft-quoted transfer of a novel onto the big screen and encompasses other types of transposition, such as TV adaptation and comic book adaptation. Notably, Elliott (2014) broadens the concept of adaptation and remarks that it is necessary to redefine adaptation as an 
intercultural or interhistorical transfer which would not necessarily involve a change in medium. "Formal and cultural, textual and contextual approaches to adaptation need to be synthesized" (Elliott 2014: 584) so as to study adaptation in its various manifestations. Andrew (1984) further stresses that the study of adaptation should examine source material and adaptation in their respective contexts. In support of this argument, Elliott (2004: 227) points out that film adaptations impute the narrative with "the semiotic richness of moving images, music, props, architecture, costumes, audible dialogue" and other modes of expression, all of which are fraught with cultural and symbolic resonances, while Carroll (2009: 38) argues that adaptation "is a product of the discourses which surround it." Moreover, Murray (2012) emphasises that there needs to be a sociological approach to the study of adaptations, which would take into account the industry that encompasses the production of books as well as films. However, the ways in which adaptations capture the zeitgeist of a period or the economic, creative and social intricacies involved in the adaptation process are relatively under-researched.

Drawing upon the above-mentioned viewpoints and the affinities between Translation Studies and Adaptation Studies, this paper puts forward a theoretical framework which conceptualises film adaptation as translation and, thus, as a context-dependent process. It is argued that the relationship between adapted material and film adaptation is influenced by the respective contexts of production and reception, a palpable representation of which is to be found in the paratext. Paratext can be viewed as a further contextual factor which reflects and enhances the communication that takes place in adaptation. Paratext (or paratextual material) is used here to refer to monomedial or multimedial texts which accompany a given product (audiovisual or otherwise) and which condition our experience of it (Genette 1997; Gray 2010). The important role of paratexts as regards the dissemination and interpretation of texts has been highlighted by theorists (see Gray 2010; Kernan 2004). Here, paratexts are employed so as to look into the rationale of the adaptation process. As a result, adaptation in this paper is approached as an instantiation of intertextual and intersemiotic transfer as well as an act of communication between texts and socio-temporal contexts.

The focus lies on film adaptation, i.e., the cinematic transposition of a novel. The framework of adaptation analysis put forward here aims to flesh out the synergies between translation and adaptation. Although it is applied to a specific film adaptation for the purposes of this paper, it is assumed that it may be applicable to other adaptation types as well as genres. After an overview of Lefevere's (1982/2012) concept of patronage, the discussion focuses on the impact of patronage on the film system. Subsequently, the context of film adaptations is defined and specific examples of adaptation shifts are examined. As used in this paper, 'adaptation shifts' refer to particularly notable changes that are observed between film adaptation and source novel. The analysis of the adaptation shifts moves beyond a mere comparison of book and film; more importantly, it aims at interpreting them holistically against the economic, creative and social backdrop of the adaptation system.

The film adaptation used as a case study is P.S. I Love You (LaGravenese 2007), ${ }^{1}$ which is based on the homonymous novel by Cecelia Ahern (2004). ${ }^{2}$ This film was chosen as representative of a genre which has traditionally been disparaged critically yet holds a quite prominent position in film production, i.e., the genre of romantic 
comedy. According to Abbott and Jermyn (2009: 2), even though romantic comedies have been considered by theorists and critics as oversimplified narratives, the genre touches upon a multitude of interests and social issues. Furthermore, its conventions are shaped through a shared cultural landscape (Abbott and Jermyn 2009: 3). As a result, it can be argued that romantic comedies reflect the values of the social context in which they are produced and received, which in turn can affect the adaptation process, especially because the filmic product as a medium addresses a much wider audience compared to the book. In addition, given that the genre is deeply rooted in the construct of interpersonal relations, it is apt for examining the manipulation of human behaviour as adapted/translated from paper to screen. P.S. I Love You is particularly interesting in this respect due to the nature of its adaptation shifts: although the plot development does not differ much from the book, the characterisation patterns undergo significant changes in the adaptation. Given that the genre of romantic comedy (to which the examined adaptation belongs) relies heavily on character construal and narrative patterns for its recognisability (McDonald 2007), the manipulation of such characteristics can assign interesting nuances to the adaptation of romantic comedies, and to adaptations in general. The analysis further resorts to paratext pertinent to the film with the aid of which the adaptation shifts are interpreted.

\section{From Lefevere's patronage to the film system}

According to Lefevere (1982/2012: 206), patronage is the influence exerted by the regulatory body in the literary system. It consists of an ideological, an economic and a status component: the ideological component requires that literature be generally in step with the other systems in a given society, the economic component ensures the writer's livelihood and the status component reflects the writer's recognised position in society. In a similar vein, the ideological component of patronage in the film system may refer to the messages that are to be conveyed by films, including film adaptations, and, as a result, it may influence the adaptation process accordingly. The economic component can be attributed to the production aspect of the film industry and the status component in the film system may refer to the reputation of the producer and the director; in the case of adaptations, it can include the reputation of the source novel's author.

Furthermore, Lefevere (1982/2012) notes that patronage influences the arrangement of works of literature within the broader literary system. The same holds for which texts are selected to be translated and for their position in the literary polysystem (Even-Zohar 1978/2012). Extending this to the case of film adaptations, it can be argued that the components of patronage have a similar impact on the adaptation process. In fact, Hutcheon (2013: 108) notes that the decisions involved in the process of adaptation often rely on factors pertinent to genre and/or medium conventions, political engagement and public history. Therefore, there is an intricate network of relations between the products (i.e., the source novel and the film adaptation) and the wider contexts in which they are produced and received. The outcome of this interaction is substantiated and solidified through the changes that are to be observed in the film adaptation.

Given this complex network of relations, adaptations cannot be judged merely on a criterion of fidelity to the novel they adapt, a viewpoint that has given rise to 
the fidelity debate in Adaptation Studies (see Andrew 2000; McFarlane 1996). McFarlane's (1996) discussion on what and how faithfully can be adapted raised issues of fidelity of the film to the original novel. The ways in which the film manipulates the narrative core of the book - and by extension how it differs from its literary predecessor - resonates with value judgements as to whether the 'spirit' or the 'essence' of the work is transferred. With regard to transferring the 'letter' and the 'spirit' of a text, Andrew (2000) notes that the former is more easily done than the latter. Nevertheless, this need not ostracise film adaptations to inferiority as artistically minor replicas; on the contrary, it opens the route to further possibilities of creative transposition of equivalent narrative units within the bounds of the separate media.

Contemporary adaptation theories have also declared the fidelity criterion as inadequate adaptation heuristics and call for a more holistic approach to the study of adaptations. According to Hutcheon (2013), adaptations assert their value by reinterpreting the source novel and assigning new messages to it. In fact, in order for film adaptations to be regarded as successful works of art in their own right, they need to be so for audiences with and without prior knowledge of the book. According to Hutcheon (2013: 174), the essence of adaptations is "the ability to repeat without copying, to embed difference in similarity, to be at once both self and Other," upon which rests their real artistic and cultural value. Stam (2000: 64) highlights that, over and above stagnant comparisons based on fidelity, adaptations enter into an intertextual dialogism with their source novels. He also points out that the original is not in an antagonising conflict with the copy, but it rather gains in prestige and cultural value through it (Stam 2005: 8).

According to this view, the adaptation process initiates a reciprocal communicative act which may work in a twofold manner. On the one hand, through rewriting and reinterpreting the adapted material, adaptations reconfigure the messages conveyed in the novel; these messages eventually acquire a new value assigned to them by the current sociocultural context. On the other hand, for those viewers not familiar with the source novel, reading the novel post-adaptation becomes the re-viewing of the adaptation; consequently, the ideas expressed through the filmic product are processed and interpreted in interaction with the wider context enveloping the novel. This feature of adaptations qualifies them as works of art with their own artistic and cultural identity. The fact that adaptations are distinctive cultural artefacts constituting a significant part of artistic production is emphasised by Andrew (2000: 37), who remarks that adaptations partake of film practices and models emerging in a particular period and hold a pivotal position in the cinematic polysystem.

In the following section, the various components of patronage as exerted in the film industry are mapped onto key facets of the context that surrounds the film adaptation and, by extension, the adaptation shifts.

\section{Adaptation and context}

As can be argued so far, the various influences arising from the film system may have an impact on the way in which film adaptations are conceptualised, produced and received. There seems to be an inherent interaction between the adaptation and its contexts of production and reception, on which the film ultimately depends for its 
accessibility and possibly its acceptability. A film adaptation encapsulates and materialises the influences exerted by the agents involved in its creation; at the same time, it needs to respond to the values and demands of the contemporary sociocultural surroundings in order to provide a reinterpretation of the source material that caters to these demands. Leitch (2008) stresses that adaptation encourages the audience to reflect on the messages conveyed by the source text and test their assumptions against those communicated by the adaptation. In this way, adaptations introduce new reading strategies (Leitch 2008: 116) through which views of social reality may be reinterpreted and restabilised.

Interestingly, Bastin (2001) notes that adaptation as a translation technique is a creative process alert to the communicative situation in which it occurs, seeking to transmit the purpose of the original text to a cultural context unfamiliar with the signs and codes of the source culture. This approach to translation, which caters to the purpose of the source text with an eye to its reception in the target culture, is called by Hickey (1998) recontextualisation. The same term is also used by House (2006) to refer to translation, since translation involves taking stretches of language out of their earlier context and placing them in a new one with new values and communicative conventions. In a similar vein, it can be argued that adaptation relocates a narrative - and, more importantly, a discursive event - into a new socio-temporal and medial context. Therefore, "adaptation is primarily a phenomenon of recontextualisation of a text, or, even better, of reformulation of its communicative situation" (Casetti 2004: 83; emphasis in the original), which is why attention should be shifted to the dialogue between text and context. According to House (2006: 342), context can be conceptualised as "encompassing external (situational and cultural) factors and/or internal, cognitive factors, all of which can influence one another in acts of speaking and listening." As regards audiovisual texts, Desilla (2012: 34) defines context as "information entertained by the viewers themselves as well as information conveyed (perceived or inferred) by the various semiotic resources" of the text. Given that adaptation involves both verbal and audiovisual texts, both definitions of context are at work.

It becomes clear then that context plays a crucial part in the way in which an adaptation is materialised. It is a complex entity with various dimensions that can be broken down into the following categories:

- The economic dimension refers to the commercial aspect of the film-making process. It pertains to the organisation of the film industry and includes the activities involved in the production, distribution and exhibition phases of film-making (Halsey, Stuart \& Co. 1985: 199). More specifically, the economic component arises from the people involved in the budgeting of the film and may cover details ranging from the machinery used within the film to the cast selection and the promotion campaign.

- The creative dimension refers to the artistic nature of film-making. It relates to the adapter's reinterpretation of the source novel and to the ways in which s/he substantiates such reinterpretation through manipulating the genre or medium conventions or through altering aspects of the narrative of the novel. The creative component can also refer to the actors' interaction with the fictional personas and their more or less ostensive interventions in the character portrayals. Such interventions could depend on the liberties allowed by the director/screenwriter but they could equally be forcefully presupposed based on the actors' to date career and reputation. 
- The social dimension entails the current socio-political circumstances which may encourage a particular re-reading and reinterpretation of the source novel (on the part of the adapter and the cast); it can also be linked to the reception of this reinterpretation (on the part of the audience and the critics). This dimension provides the backdrop against which the adaptation recontextualises the source material and incorporates the social spectra through which the receivers of the adaptation process and interpret the cinematic transposition (and the source novel).

The adaptation context may also include material relevant to the adaptation process, i.e., paratext extending from the marketing campaign of the film (which could interweave with the source novel's re-advertising) to the production and postproduction phases of film-making. Gray (2010) identifies two broad categories of paratexts, namely "those that control and determine our entrance to a text - entryway paratexts - and those that inflect or redirect the text following initial interaction - in medias res paratexts" (Gray 2010: 35; emphasis in the original). In a similar way that translations can be better understood when examined against the specific context that accommodates them, the various contextual factors at play in the broader film system can provide a better insight into adaptations. Paratextual material may cover any of the following:

- Interviews of the author of the source novel, the screenwriter and/or director and the cast of the adaptation;

- The film trailer, where the baseline of intertextual reference to the novel is established (or not) and where expectations are created;

- Reviews of the film, both as an artistic creation in its own right and as a cinematic transposition of a literary work;

- Viewers' comments on the film;

- Reviews of the source novel, which indicate its strengths and weaknesses and are a general guide to its reception, and

- Readers' comments on the book.

This is not an exhaustive list, yet it includes key paratextual features that could help deconstruct the communication between source novel and film adaptation. The paratext can be used as a benchmark to explain the changes that occur in the adaptation in terms of their conceptualisation by the adapter as well as their reception by the audience (including both professional critics and habitual cinephiles).

The following section analyses three adaptation shifts observed in P.S. I Love You (LaGravenese 2007) which are then interpreted with the aid of relevant paratext. The employed paratext includes material from the first three categories as outlined above. More specifically, the analysis makes reference to:

1) Interviews of the author, the director and the cast:

a. Ahern's interview, where she discusses the changes made during the adaptation of her novel;

b. Two interviews of LaGravenese on his interpretation of the novel and casting choices;

c. One interview of Gerard Butler (Gerry), one interview of Harry Connick Jr. (Daniel) and two interviews of Jeffrey Dean Morgan (William).

2) The film trailer;

3) A film review (Calamari). ${ }^{3}$ 


\section{An analysis of adaptation shifts in P.S. I Love You}

P.S. I Love You (Ahern 2004) is a romantic novel recounting the story of Holly, a young widow who tries to come to terms with her husband's death and move on with her life. This process of recovery is punctuated by letters which Gerry (Holly's husband) wrote before his death and which he arranged for Holly to receive every month for one year after his death. The letters initially encourage Holly to make the first steps towards reconciling with Gerry's absence and progressively urge her to make life-changing decisions, such as pursuing the job of her dreams. As a film adaptation, P.S. I Love You was directed by Richard LaGravenese (who also wrote the screenplay along with Steven Rogers) and was released at Christmas, 2007, with Hilary Swank as Holly and Gerard Butler as Gerry. The adaptation overall maintains the structure of the story plot. However, it features key differences in the representation of the fictional characters, as pointed out in the Introduction, which in turn interfere with the interpersonal dynamics of the film. The analysis focuses on three adaptation shifts, namely (i) the emphasis placed on Gerry's character, (ii) the addition of a male character (William) and (iii) the sensualisation of the female protagonist.

\subsection{The accentuation of Gerry's presence}

While the book casts the spotlight on Holly, closely registering her thoughts and actions as she goes through the grieving process, the film presents her experiences as observed and often foreshadowed by Gerry. In the novel, Gerry's presence depends on Holly's reminiscence of their past. His character reaches readers as mediated through memories. Therefore, it can be argued that readers get to know him as Holly remembers him, a lens which may be distorting given that it is uncommon to think or talk negatively about the deceased (Wright 2007: 14). The most direct encounter that readers have with Gerry is instantiated through his letters. These allow readers to infer the particulars of his character by means of his word choices and style of writing. ${ }^{4}$ As far as the film is concerned, the opening scene is a flashback from when Gerry was alive, which is not one of Holly's memories, though. The scene introduces the two main characters, the setting and details of their relationship, while it underlines Holly and Gerry's intense and loving relationship; the couple is shown having an argument over practical issues, such as work and money, and issues related to their future as a couple, such as having a baby. Through this heated argument, signified both physically and verbally, comes an emotional climax which brings passion and deep love to the fore. This is where viewers have the opportunity to directly experience Gerry and, for those familiar with the source novel, establish a baseline of reaction to his cinematic incarnation.

Gerry's character in the film acquires deeper dimensions compared to the novel. It is worth noting that Gerry appears physically through flashbacks and through Holly's imagination up until a particular point (01:32:37). Given that the film's duration is 126 minutes, it can be argued that he dominates the film until that point. This seems to be a change approved by the author. In fact, Ahern felt that Butler's personality and acting style dovetailed Gerry's character in an incredibly fitting manner (Ahern 2007). ${ }^{5}$ Moreover, in one of his interviews on the film, LaGravenese has mentioned that Gerry's role could only be played by Gerard Butler because he embodied masculinity and sensitivity in the very way described in the novel (LaGravenese 
2007a). ${ }^{6}$ Therefore, Butler's suitability for the role may have served as a springboard for the adapter's allowing Butler to mould Gerry's persona more elaborately. In addition, Butler has admitted that he enjoyed playing Gerry because this role gave him for the first time the chance to enact human and emotional relationships while tiptoeing to subtle funniness (Murray 2007a). ${ }^{7}$ In other words, Butler treated this role as a refreshing acting opportunity, trying to showcase aspects of his performing repertoire not exhibited until then.

Apart from reasons of creative licence, this adaptation shift may also be explained from an economic angle. The film was promoted as a romantic comedy in the trailer, creating the expectation of a heart-warming story conveniently released at Christmas (Linton 2007). ${ }^{8}$ According to Kernan (2004), film trailers aim to tease prospective viewers by presenting a finely edited selection of the most spectacular scenes of a film. In this way, they act as an anticipatory device, promoting the given feature film and encouraging movie-going in general. In addition, as McDonald (2007) notes, the genre of romantic comedy has been traditionally linked with a female target audience. Casting Gerard Butler can be seen as an effort to appeal to female viewers, since his physique had attracted much attention in 300 (Snyder 2006). ${ }^{9}$ This point is made both by a film reviewer (Calamari.) and by a (female) interviewer at the premiere of the film, who congratulates LaGravenese on his casting choices of Butler and Jeffrey Dean Morgan (William). Therefore, the amplification of Gerry's role may be viewed as a move towards ensuring a box-office success, which also links to the following adaptation shift, namely the inclusion of a new character in the film adaptation.

\subsection{The addition of a male character}

Jeffrey Dean Morgan (William) had gained quite a number of fans through his appearance in Grey's Anatomy (Rhimes 2005) ${ }^{10}$ which was where LaGravenese discovered him. Morgan's appeal to the female audience is underlined both in one of his interviews (Murray 2007b) ${ }^{11}$ and in two of LaGravenese's interviews, where the director talks about his selection of the cast (LaGravenese 2007a; 2007b). ${ }^{12}$ Furthermore, Grey's Anatomy won the Golden Globe for "Best Television series (Drama)" in 2007 (the same year that P.S. I Love You was released) and secured many nominations for its cast (Imdb). ${ }^{13}$ As a result, casting Morgan may have been motivated by the critical acclaim of the TV series and by the potential of investing in his expansive fan-base, thus qualifying him as a promising asset in the box-office.

Interestingly, Morgan's character does not exist in the novel; William is a brandnew love interest of Holly's in the film. In the book, it is suggested that Holly develops romantic feelings for another man, Daniel, with whom she has a weirdly honest friendship in the adaptation. However, these feelings are not eventually fulfilled in the novel. As a result, Holly and Daniel remain friends in the book as well. Interestingly, a romantic relationship for Holly is only implied towards the end of the book, while it is not confirmed whether it reaches completion. On the contrary, the film adaptation strongly suggests that Holly and William end up together, thus complying with the happy-ending convention of the romantic comedy genre.

The relevant paratext does not provide any information on the addition of William's character. Nonetheless, it is worth noting that William is a childhood friend of Gerry's and resembles him in many respects: he is Irish, he dresses similarly, 
he plays the guitar and sings and, finally, he becomes intimate with Holly. This is why he can also be seen as Gerry's replacement, since it is strongly suggested towards the end of the film that he and Holly end up together. Put differently, William represents a new (romantic) beginning after a beloved one's death, an issue which is sometimes socially criticised. Given that LaGravenese wanted to stress the process of self-discovery after a loss (LaGravenese 2007b), the addition of William's character could have been inspired by such social considerations.

On the other hand, the adapter's aspiration to 'revolutionise' the genre and remodel its conventions may have contributed to the manipulation of Holly's character, as will be argued.

\subsection{The sensualisation of Holly's character}

LaGravenese wished to give a fresh reinterpretation to the genre of romantic comedy (LaGravenese 2007a) and this was manifested through casting as the female protagonist an actress with a relatively more hardcore acting career until then. As he explains, he had worked with Swank in Freedom Writers (LaGravenese 2007) ${ }^{14}$ where he admired her acting malleability. LaGravenese wanted to emphasise Swank's beauty and give her the opportunity to play a glamorous role, sharply contrasting her prior gamut (LaGravenese 2007b).

The adapter's creative stance could thus account for the adaptation shift that relates to the manipulation of the female protagonist and, in particular, to the treatment of her physical appearance. In the novel, Holly is not presented as outstandingly beautiful or sexy. In fact, given her thirtieth birthday, there are many references to her getting older and being unable to dress - or drink - in the way younger women do (Ahern 2004: 145). References to her physique concern mainly the weight she had lost due to her grief. Arguably, this is expected after experiencing such a shock as was Gerry's death. However, even as her psychological state improves, descriptions of her physical appearance are moderate, without exaggerations regarding her looks. Moreover, she usually wears black which matches her mood (Ahern 2004: 153); her outfits are described but there are no extravagant comments on how good she looks. Even as she gradually recovers from her loss, descriptions of her physical appearance are moderate; her outfits (usually black) are described but there are no extravagant comments on how good she looks.

On the other hand, the film portrays Holly as a very good-looking woman, who appears pretty and elegant even as a widow in mourning. Her stylistic choices are smart and sophisticated throughout the course of the film, with the exception perhaps of her wearing Gerry's shirt and underpants the first days after his death or of her markedly colourful outfit when she first meets Gerry. Furthermore, her shoe racks are particularly noticeable at key points in the film: at the beginning (quite ironically so as the couple argue over financial issues and limited space in the apartment), where Holly's style is established, and when Holly has an 'epiphany' on her dream job, namely a shoe-designing career pathway.

An interesting case in point which further underlines the emphasis placed on Swank's physical attributes is the cinematic transposition of a karaoke incident. The following extract from the novel describes the embarrassing accident Holly has as she stands on the stage quite drunk, singing Madonna's Like a Virgin: 
As soon as she started singing, Holly had never heard so many boos in her whole life and at such a loud volume. [...] Eventually, when people began to throw things at the stage, and when the karaoke host himself encouraged them to boo even louder, Holly felt that her work there had been done. [...] There were all the more people to see Holly trip down the steps in her stilettos and fall flat on her face. They all watched as her skirt went flying over her head to reveal the old underwear that had once been white was now gray, and that she hadn't bothered to change when she got home from work. (Ahern 2004: 120)

It becomes clear then that Holly is presented in the novel as an ordinary woman, clumsy and ungraceful at times. However, she also has positive qualities, such as resilience, kindness and honesty, which counterbalance her flaws and are progressively revealed in the course of the novel.

In the film, the karaoke incident is presented under a completely different light. The audience is cheering Holly to the stage and gets even more enthusiastic as she begins what looks like a very well thought-through performance. ${ }^{15}$ She sings Prince's Gett Off, which can be considered as the exact opposite of Like a Virgin, since it features overt sexual innuendo and thus undercuts the assumed innocence conveyed by the latter song in the respective scene of the book. Moreover, as Gett Off cues, closeups show Holly unbuttoning her shirt to reveal a deep cleavage, lowering dangerously her skirt and swaying her hips, while the camera focuses on her slender and toned physique. These shots, accompanied by the erotic beat of Gett Off, sensualise Holly and foreground her sexuality, an aspect not explored in the novel. What is more, just before starting singing, Holly removes her hair-band and playfully throws it to Gerry, a move that reminds of striptease. At the same time, the crowd erupts in cheers and the camera alternates between Holly's performance and Gerry's surprise and amusement.

Comparing the scene so far to its novelistic counterpart, it can be seen how differently Holly is introduced to the crowd and the disparate expectations that are created. In the film, Holly performs a show with distinctly sexual overtones and she is objectified in the eyes of the beholders. Her objectification is further underscored by the camera movements, as the shots literally fragmentise her, focusing first on her bust, then on her stomach and finally on her legs (and high heels) and hips. Even as she starts singing, the cheering does not subside, since her voice is easy on the ears. Her performance maintains the eroticism of the beginning: the lyrics are explicitly sexual, Holly caresses her body and the overall performance looks like an erotic invitation to Gerry. Alternate shots focus on Gerry's reactions of disbelief and excitement and create a kind of dialogue between them. The only thing that disrupts the otherwise masterly performance is the accident at the end of the scene, when Holly trips over some cables to the audience's horror and disappointment. The next scene shows Holly and Gerry at the hospital where she lies with a bandaged broken nose and bloody teeth. Although both the novelistic and the cinematic instances feature an accident, the publicly humiliating underwear-exposing accident of the book is remarkably toned down in the film, leaving Holly's dignity relatively unscathed and not overwriting her prior sensual performance.

The shifts regarding the portrayal of the female protagonist can be seen as motivated by the adapter's re-interpretative stance towards the genre of romantic comedy. Additionally, the sensualisation of Holly's cinematic persona may stem from an effort 
to present the film as a product capable of reaching male viewers as well. As actors Harry Connick Jr. (Daniel) and Jeffrey Dean Morgan (William) point out in their premiere interviews, the film addresses equally female and male viewers because it involves issues that can touch everybody without being too sentimental (Connick Jr., $2007 ;^{16}$ Morgan, 2007 ${ }^{17}$ ). The same argument is put forward by the director, who explains that the film is a love story but also deals with self-discovery, friendship and family relations (LaGravenese, 2007b). However, it can also be argued that, in order for the film to communicate its messages to a male audience, it first needs to capture their attention. This is where Holly's amplified femininity comes into play, acting as an eye-catcher and possibly as an attention-retainer. In other words, the alteration of Holly's portrayal in the film adaptation affirms the adapter's aspiration to remould the generic conventions but at the same time satisfies the economic principles of the film industry, by broadening the range of the target audience. In addition, the values of friendship and family are always topical and socially prevalent, reflecting people's need for a cinematic depiction of personal relationships. The capacity of the romantic comedy to adapt itself to the sociocultural context thereby responding to such demands has ensured the continuing popularity of the genre (Deleyto 2003: 168).

\section{Conclusion}

This paper has argued that, similarly to translation, the film adaptation process initiates an act of communication between the source novel, the end film product and the involved contexts of production and reception. Drawing upon the affinities between translation and adaptation, the theoretical part of the paper used Lefevere's patronage (1982/2012) in order to account for the various contextual factors involved in the adaptation process; paratext was posited as an important aspect of context which enhances the communicative act realised through the adaptation. Paratext was employed as a useful tool in the study of certain adaptation shifts. It was, therefore, concluded that a closer look at the context enveloping adaptations can give rise to a more in-depth understanding thereof.

The analysis of three adaptation shifts from the film P.S. I Love You (LaGravenese 2007) suggested that adaptation shifts may be motivated by economic, artistic and social incentives, or a combination of the above. The evidence provided by the paratext indicated that the emphasis placed on the male protagonist, Gerry, was encouraged by artistic considerations. More specifically, the adapter capitalised on Butler's suitability for the role and, thus, allowed the character a greater space than that given to him in the novel. Moreover, economic incentives relating to the profitability of the film buttressed the casting choices of both Gerard Butler and Jeffrey Dean Morgan. It was suggested that economic as well as social motivations may have had a bearing on the addition of Morgan's character (William), given the attention he had attracted in Grey's Anatomy and the social nuances of his role in the adaptation. Finally, the sensualisation of Holly's character was put forward as an adaptation shift motivated by a combination of creative, economic and social reasons: this change was analysed as resulting from the director's endeavour to reshape the genre of romantic comedy, from an audience-widening strategy, thus maximising the profit potential of the film, and from an intensification of the social dimension of the film, namely the treatment of issues such as self-discovery, friendship and family relations. 
As the case study illustrated, the process of transposing a novel onto the cinematic screen is a context-dependent communicative act (similarly to translation), which involves the source novel, the film adaptation and various contextual factors. Therefore, it can be argued that the points above highlight the multifaceted communication initiated by the adaptation as a process as well as a product: as a process, adaptation fosters a dialogue between the context of the source material and the contemporary sociocultural circumstances that accommodate adaptation as a product; adaptation as a product contributes to the inter-textual dialogue by inviting the renegotiation of ideas and messages transmitted by the adapted material, under the light of the current status quo. Ultimately, the ways in which such reinterpretation reaches the audience are dependent on the various factors that monitor the production and reception of adaptations, a point which echoes Lefevere's patronage (1982/2012). Paratext can be used to investigate the rationale behind adaptation shifts and it may serve as a barometer of film-making practices in the film polysystem of a given society and era. Consequently, paratext may act as a quite reliable yardstick for the analysis of adaptation shifts, as opposed to the uncompromising criterion of fidelity.

This paper relied mainly on film-oriented paratext to interpret the occurring adaptation shifts (with the exception perhaps of Ahern's interview, which can be seen as bridging book and film). Furthermore, apart from one film review which expressed approval of Butler's deployment, it focused on the production side of the adaptation process, investigating how agents involved in the film-making process conceptualise the adaptation. Further research could look into paratext pertinent to the adapted material and, additionally, into the reception of both products. Examining adaptation from this perspective could yield an insight into how the audience (comprising of critics and viewers) perceives and interprets the occurring adaptation shifts.

\section{NOTES}

1. P.S. I love you (2007): Directed by Richard LaGravenese. United States: Warner Bros. Pictures.

2. Ahern, Cecelia (2004): P.S. I love you. London: Harper Collins.

3. Calamari, Alexandra (n.d.): Movie review: P.S. I love you. Cinemablend. Visited on 8 May 2015, $<$ http://www.cinemablend.com/reviews/P-S-I-Love-You-2797.html >.

4. Interestingly, although the novel uses stylised italics formatting to represent the originality of Gerry's letters, the film allows viewers to access Gerry's supposed handwriting through close-ups on the letters, thus enhancing the deduction process.

5. Ahern, Cecelia (2007): A conversation with author Cecelia Ahern. In P.S. I Love You [DVD]. United States: Cupid.

6. LaGravenese, Richard (2007a): P.S. I love you: Richard LaGravenese interview. Youtube. Visited on 8 May 2015, <http://www.movieweb.com/movie/p-s-i-love-you/richard-lagravenese-interview >.

7. Murray, Rebecca (2007a): Gerard Butler discusses 'P.S. I love you.' About.com. Visited on 8 May 2015, <http://movies.about.com/od/psiloveyou/a/psilovegb121207.htm>.

8. Linton, Dayna (2007): 'P.S. I love you' movie trailer. Youtube. Visited on 8 May 2015, <https:// www.youtube.com/watch?v=3GNxdc-wlw4>.

9. 300 (2006): Directed by Zack SNyder. United States: Warner Bros. Pictures.

10. Grey's anatomy (2005): Produced by Shonda Rhimes. United States: ABC.

11. Murray, Rebecca (2007b): Jeffrey Dean Morgan discusses 'P.S. I love you.' About.com. Visited on 8 May 2015, <http://movies.about.com/od/psiloveyou/a/psilovejm121407.htm>.

12. LaGravenese, Richard (2007b): Richard LaGravenese interview - P.S. I love you. Youtube. Visited on 8 May 2015, <https://www.youtube.com/watch?v=545U2GuoawE $>$.

13. Internet Movie Database (IMDb): Visited on 8 May 2015, <http://www.imdb.com/title/tt0413573/ awards?ref_=tt_awd $>$. 
14. Freedom writers (2007): Directed by Richard LaGravenese. United States: Paramount Pictures.

15. Arguably, the events and actions of a film are predetermined by the script. Nevertheless, Holly's performance could have been differently represented, interspersed with more diffident and amateurish moves.

16. Connick JR., Harry (2007): Harry Connick Jr. interview - P.S. I love you. Youtube. Visited on 8 May 2015, <https://www.youtube.com/watch?v=iT_AF2RMm0E $>$.

17. Morgan, Jeffrey Dean (2007): Jeffrey Dean Morgan interview - P.S. I love you. Youtube. Visited on 8 May 2015, <https://www.youtube.com/watch?v=C-fvEk7P2Bw>.

\section{REFERENCES}

Аввотт, Stacey and Jermyn, Deborah (2009): Falling in Love Again: Romantic Comedy in Contemporary Cinema. London: I.B. Tauris \& Co.

Andrew, Dudley (1984): Concepts in Film Theory. Oxford and New York: Oxford University Press.

Andrew, Dudley (2000): Adaptation. In: James Naremore, ed. Film Adaptation. New York: Rutgers, 28-37.

Aragay, Mireia (2005): Introduction. Reflection to refraction: Adaptation Studies then and now. In: Mireia Aragay, ed. Books in Motion. Adaptation, Intertextuality, Authorship. Amsterdam: Rodopi, 11-34.

Bastin, Georges L. (2001): Adaptation. In: Mona BAKer, ed. Routledge Encyclopedia of Translation Studies. London and New York: Routledge, 5-8.

Carroll, Rachel (2009): Affecting fidelity: adaptation, fidelity and affect in Todd Haynes's Far From Heaven. In: Rachel Carroll, ed. Adaptation in Contemporary Culture: Textual Infidelities. London: Continuum, 34-45.

Casetti, Francesco (2004): Adaptation and mis-adaptations: film, literature and social discourses. In: Robert StAm and Alessandra Raengo, eds. A Companion to Literature and Film. Oxford: Blackwell, 81-91.

Catrysse, Patrick (2014): Descriptive Adaptation Studies: Epistemological and Ethodological Issues. Antwerp and Apeldoorn: Garant.

Chatman, Seymour (1978): Story and Discourse: Narrative Structure in Fiction and Film. Ithaca and London: Cornell University Press.

Corrigan, Timothy (2014): Adaptations, refractions, and obstructions: the prophecies of André Bazin. Falso Movimento. Visited 8 May 2015, <revistafalsomovimento.com/adaptationsrefractions-and-obstructions-the-prophecies-of-andre-bazin-timothy-corrigan/>.

Deleyto, Celestino (2003): Between friends: love and friendship in contemporary Hollywood romantic comedy. Screen. 44(2):167-182.

Desilla, Louisa (2012): Implicatures in film: construal and functions in Bridget Jones romantic comedies. Journal of Pragmatics. 44(1):30-53.

Doloughan, Fiona J. (2011): Contemporary Narrative: Textual Production, Multimodality and Multiliteracies. London: Continuum.

Elliott, Kamilla (2004): Literary film adaptation and the form/content dilemma. In: MarieLaure Ryan, ed. Narrative Across Media: The Languages of Storytelling. London and Lincoln: University of Nebraska Press, 220-243.

Elliott, Kamilla (2014): Rethinking formal-cultural and textual-contextual divides in Adaptation Studies. Literature Film Quarterly. 42(4):576-593.

Even-Zohar, Itamar (1978/2012): The position of translated literature within the literary polysystem. In: Lawrence Venuti, ed. The Translation Studies Reader. $3^{\text {rd }}$ ed. London and New York: Routledge, 162-167.

Genette, Gérard (1997): Paratexts: Thresholds of Interpretation. Cambridge: Cambridge University Press.

Gray, Jonathan (2010): Show Sold Separately: Promos, Spoilers, and Other Media Paratexts. New York and London: New York University Press. 
Halsey, Stuart \& Co. (1985): The motion picture industry as a basis for bond financing. In: Tino Balio, ed. The American Film Industry. $2^{\text {nd }}$ ed. Madison: University of Wisconsin Press, 195-217.

Hickey, Leo (1998): Perlocutionary equivalence: marking, exegesis and recontextualisation. In:

Leo Hickey, ed. The Pragmatics of Translation. Clevedon: Multilingual Matters, 217-232.

House, Juliane (2006): Text and context in translation. Journal of Pragmatics. 38(3):338-358.

Hutcheon, Linda (2013): A Theory of Adaptation. $2^{\text {nd }}$ ed. London and New York: Routledge.

Jenkins, Henry (2006): Convergence Culture: Where Old and New Media Collide. New York:

New York University Press.

Kernan, Lisa (2004): Coming Attractions: Reading American Movie Trailers. Austin: University of Texas Press.

Krebs, Katja (2012): Translation and adaptation - two sides of an ideological coin. In: Lawrence

RAw, ed. Translation, Adaptation and Transformation. London: Continuum, 42-53.

Lefevere, André (1982/2012): Mother Courage's cucumbers: text, system and refraction in a theory of literature. In: Lawrence Venuti, ed. The Translation Studies Reader. $3^{\text {rd }}$ ed. London and New York: Routledge, 203-219.

Leitch, Thomas: (2008): Adaptation, the genre. Adaptation. 1(2):106-120.

McDonald, Tamar Jeffers (2007): Romantic Comedy: Boy Meets Girl Meets Genre. London and New York: Wallflower.

McFarlane, Brian (1996): Novel to Film. An Introduction to the Theory of Adaptation. Oxford: Oxford University Press.

Milton, John (2009): Translation Studies and Adaptation Studies. In: Anthony Pym and Alexander Perekrestenko, eds. Translation Research Projects 2. Spain: Intercultural Studies Group, 51-58.

Murray, Simone (2012): The Adaptation Industry: The Cultural Economy of Contemporary Literary Adaptation. New York and London: Routledge.

Stam, Robert (2000): Beyond fidelity: the dialogics of adaptation. In: James NAremore, ed. Film Adaptation. New York: Rutgers, 54-76.

StA Alessandra Raengo, eds. Literature and Film: A Guide to the Theory and Practice of Film Adaptation. Oxford: Blackwell, 1-52.

VANDAL-Sirois, Hugo and BASTin, Georges L. (2012): Adaptation and appropriation: Is there a limit? In: Lawrence Raw, ed. Translation, Adaptation and Transformation. London: Continuum, 21-41.

Venuti, Lawrence (2007): Adaptation, translation, culture. Journal of Visual Culture. 6(1):25-43.

Wagner, Geoffrey (1975): The Novel and the Cinema. London: Tantivy Press.

Wright, Bob (2007): Loss and Grief. Keswick: M\&K. 